\title{
Heat transfer by three types of hot pack and its implication on the flexibility of the lower back: a randomized, controlled trial
}

Transferência de calor por três tipos de compressas quentes e sua implicação na flexibilidade da região lombar: ensaio clinico randomizado e controlado

Transferencia de calor por tres tipos de compresas calientes y su implicación en la flexibilidad en la región lumbar: ensayo clínico aleatorio y controlado

Paulina Fuentes-León', Natalia Jara-Poblete', Pía Bastías-Sánchez', Kaio Fernando Vitzel2,3, Gabriel Nasri Marzuca-Nassr ${ }^{1,2}$

\begin{abstract}
The use of hot pack is a common superficial thermotherapy strategy and one of its benefits is the increase of muscle flexibility. However, there is a lack of information about the effects of the heat pack alone, without being used in association with other therapeutic interventions, in the flexibility of the lumbar region. The aim of this study was to compare the effects generated by the application of three different pack on the flexibility of the lower backs of healthy students. Three sessions of 15 minutes of superficial heat through a hot pack (moist heat packMHP, seed pack-SP or gel pack-GP) were applied to the lower back. Pack and lower back temperatures and erythema were registered every 5 minutes. A Schober test was performed before the first session and after the third session. After 15 minutes of treatment, pack temperature was higher in the SP group. At the same time, lumbar temperature was lower in the GP group. The heat treatment also increased erythema in the lower back for all three groups. There was a significant increase in intragroup flexibility as assessed by the Schober Test for all groups. There are significant differences in the effect generated between the three types of pack on the flexibility of the lower back. The MHP was able to transfer more heat to the lumbar area and provided a more pronounced increase in the flexibility of lower back tissues.
\end{abstract}

Keywords | Lumbosacral Region; Physical Therapy Modalities;
RESUMO | O uso de compressas quentes é uma estratégia de termoterapia superficial amplamente utilizada e um de seus benefícios é o aumento da flexibilidade muscular. Porém, existem poucas informações sobre os efeitos das compressas quentes, quando não associadas a outras intervenções terapêuticas, na flexibilidade da região lombar. O objetivo do seguinte trabalho foi comparar os efeitos gerados pela aplicação de três tipos diferentes de compressas quentes na flexibilidade da região lombar de estudantes saudáveis. Três sessões de 15 minutos de calor superficial aplicado através de compressas quentes (compressa úmida quente, compressa de sementes e compressa de gel). A temperatura da compressa e da região lombar e a ocorrência de eritema foram registradas a cada 5 minutos. $O$ teste de Schober foi realizado antes da primeira e após a última sessão. Após 15 minutos de tratamento, a compressa de sementes apresentou maior temperatura final. No mesmo período, a menor temperatura lombar foi obtida pela compressa de gel. O tratamento com os três tipos de compressa aumentou a ocorrência de eritema e causou aumento significativo da flexibilidade da região lombar avaliada pelo teste de Schober. Existem diferenças significativas no efeito gerado pelos três tipos de compressas quentes sobre a flexibilidade da região lombar. A compressa úmida quente proporcionou maior transferência de calor para a região lombar e propiciou um aumento mais pronunciado da flexibilidade da região lombar.

Descritores | Região Lombossacral; Modalidades de Fisioterapia; 
RESUMEN I El empleo de compresas calientes es muy utilizado por la termoterapia superficial como forma de aumentar la flexibilidad muscular. Pero son pocas las informaciones sobre sus efectos, cuando asociadas a otras intervenciones terapéuticas, en la flexibilidad de la región lumbar. Este estudio tiene el objeto de comparar los efectos de la aplicación de tres tipos distintos de compresas calientas en la flexibilidad de la región lumbar en estudiantes saludables. Fueron tres sesiones de quince minutos de calor superficial aplicadas a través de compresas calientes (compresa húmeda, compresa de semillas y compresa de gel) en la región lumbar de estos participantes. Se registraban cada cinco minutos la temperatura de la compresa y de la región lumbar y la existencia de eritema. Se empleó la prueba de Schober realizada antes de la primera y después de la última sesión. Tras quince minutos de tratamiento, la compresa de semillas presentó una temperatura final mayor. En este mismo periodo, la menor temperatura lumbar la registró la compresa de gel. El tratamiento con tres tipos de compresas aumentó la existencia de eritema y el significativo aumento de la flexibilidad de la región lumbar, evaluado por la prueba de Schober. Diferencias significativas ocurrieron con el empleo de los tres tipos de compresas calientes sobre la flexibilidad de la región lumbar. La compresa húmeda caliente tuvo una transferencia de calor para la región lumbar mayor, por lo que aumentó más la flexibilidad de la región evaluada. Palabras clave | Región Lumbosacra; Modalidades de Fisioterapia.

\section{INTRODUCTION}

The use of various agents in physiotherapy aids in the recovery process of corporal tissues. Thermotherapy uses the benefits of heat through different application method, which can be deep or superficial. One of the most common superficial thermotherapies is the use of hot pack. Among its benefits are an initial increase in blood flow $^{1,2}$, muscle relaxation ${ }^{3}$, antispasmodic effect ${ }^{3,4}$, decreased fatigue and excitability ${ }^{2}$, increased muscle flexibility ${ }^{2,3,5}$, decreased joint stiffness ${ }^{6-8}$, and increased elastic properties ${ }^{5,7}$. In recent years there was an increase in the belief and use of alternative medicine methods, such as the therapeutic use of seed pack to relieve pain and decrease muscle contractures, mainly contributing in solving musculoskeletal problems ${ }^{9,10}$.

Despite the fact that hot pack are commonly recommended by some health professionals due to their economical and easy use, there is a lack of information about the real capability of different types of pack to maintain and transfer heat ${ }^{11}$, such as moist heat, seeds and gel pack. Studies about superficial heat effects, through the application of hot pack, are usually associated with other therapeutic techniques (e.g., elongation). Therefore, the specific effect of the hot pack therapy cannot be clearly identified. Surely, this lack of information is something to worry about in physiotherapy, considering the everyday outpatient administrations which have used hot pack. It is therefore necessary to establish which of the various types of existing pack present better thermal properties for therapeutic practice.
In order to determine the efficiency of different types of pack, this study aims at comparing the effects generated through superficial heat transfer by the application of three types of hot pack on the flexibility of the lower back of healthy, male students between the ages of 18 and 25 from the Catholic University of Maule (UCM), Talca, Chile.

\section{METHODOLOGY}

This randomized double-blind controlled longitudinal study was approved by the Bioethics Committee of UCM, Chile. It is also in agreement with the Human and Animal Rights requirements of the International Committee of Medical Journal Editors' Uniform Requirements for Manuscripts Submitted to Biomedical Journals. The Consolidated Standards of Reporting Trials (CONSORT) Statement was used as a guideline for the study (Figure 1).

\section{Participants}

Three groups were randomly assigned using the online tool from http://www.graphpad.com/quickcalcs/ index.cfm ${ }^{12}$, each one consisting of 15 healthy students from UCM between 18 and 25 years old with normal body mass indexes (18.5 to $\left.25 \mathrm{~kg} / \mathrm{m}^{2}\right)$. A total of 45 participants were evaluated based on a sample calculation using an interval of confidence of $95 \%$ and a standard error of $5 \%{ }^{13}$. In the first session an interview was performed in order to record medical history and 


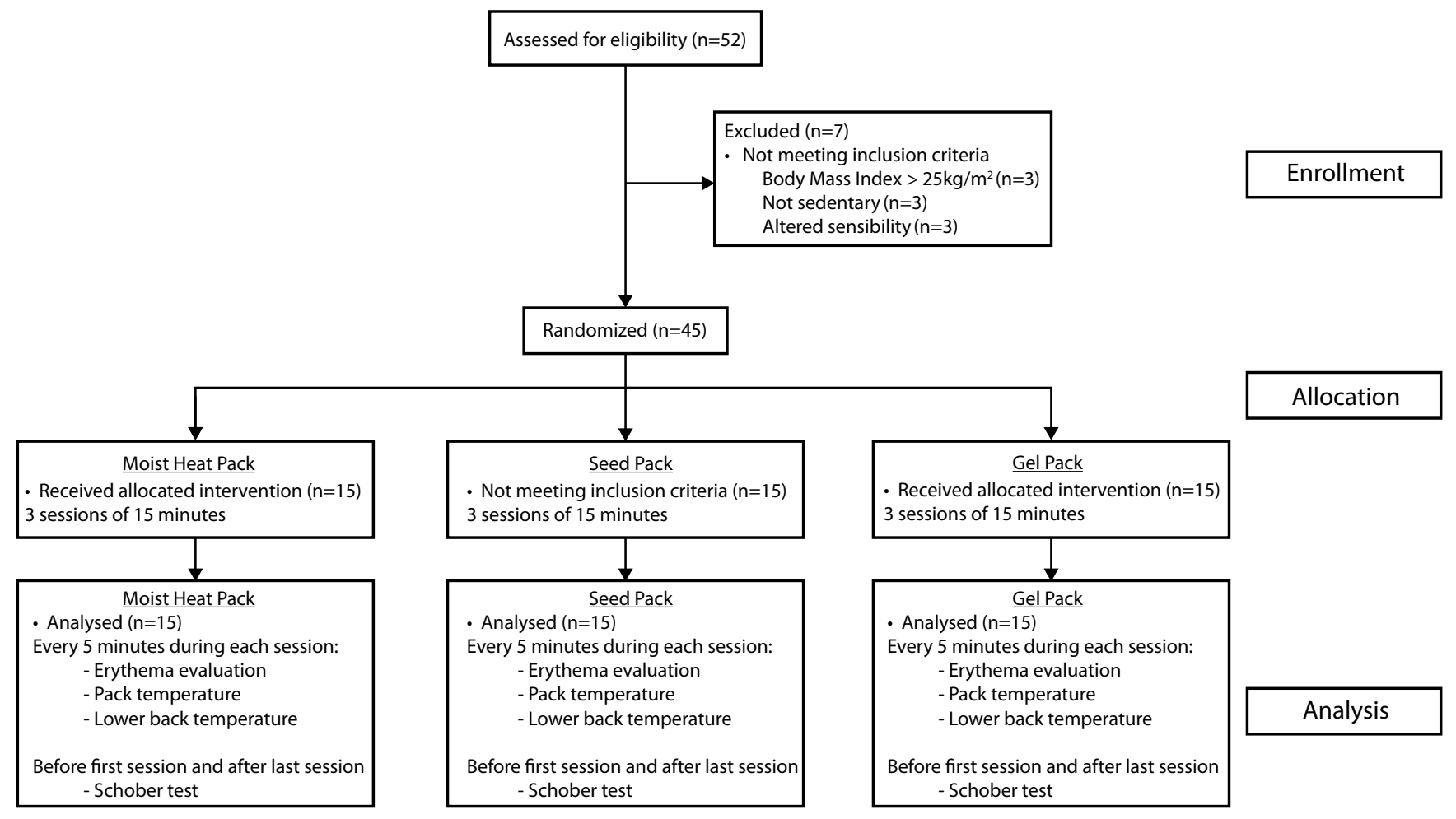

Figure 1. Consolidated standards of reporting trials (CONSORT) flow diagram of the randomized trial

health status, explain the study and obtain the informed consent signature. The exclusion criteria included recent scars or wounds on the lower back region, history of peripheral vascular diseases, impaired sensitivity, "not sedentary" (sports practice equal to or more than 3 times per week), body mass index above $25 \mathrm{~kg} / \mathrm{m}^{2}$ and a fat index above $14 \%$ according to Faulkner's formula.

\section{Procedures}

A different type of hot pack was applied in the lower back of each subject: moist heat pack (MHP) (Enraf Nonius BV ${ }^{\circledR}$ Enno Moist $25 \times 30 \mathrm{~cm}$, Model 3448167, Netherlands), seed pack (SP) (craft $25 \times 30$ $\mathrm{cm}$, Talca, Chile) or gel pack (GP) (Flexipack ${ }^{\circledR} 25 \times 30$ cm, Model Nav11, Chattanooga Group, Hixson, TN, USA) following the manufacturer's guidelines and in accordance with clinical practice for 15 minutes for 3 consecutive days ${ }^{14}$. On day one, prior to the application of the pack, the initial evaluation of flexibility of the lumbar spine of each subject was recorded using the Schober test. On day 3, after the application of each pack, the final evaluation of the flexibility of the lower back was performed using the same test. During the sessions, the temperature of the lumbar area, the temperature of the pack and the pigmentation change of the lumbar area were assessed every 5 minutes through a photographic record.

In order to carry out this study, three evaluators were needed. Evaluator number 1 performed skinfold measurements (tricipital, subscapular, supra-iliac and abdominal) and initial and the final Schober tests for each subject. Evaluator number 2 selected the pack to be assessed and performed the temperature measurements of the lumbar area and pack. Evaluator number 3 performed the task of taking pictures before and after each session, applied the Bedford scale for thermal comfort sensation and recorded the data. Evaluators number 1 and 3 did not know to what type of pack each subject was exposed. The application of each type of pack was made for a group of 15 subjects, separately for each group, during 3 consecutive days in the same week, without having knowledge of the type of pack designated to each subject. The study was carried out in a bright room at a temperature of $21^{\circ} \mathrm{C}$, each subject was comfortably placed on a stretcher in prone position, with a cushion in the abdominal area and forefoot zone.

The method used to assess the flexibility was the Schober Test. In order to perform the evaluation, the patient was placed in a standing position with his bare feet slightly apart; two points were marked on the skin, one above the spinous apophysis $\mathrm{S} 1$ and another point 
$10 \mathrm{~cm}$ above that mark. The patient performed a maximal trunk flexion without flexing the knees and the increase of the distance between the two marks was recorded. After this evaluation, the pack was applied to the lower back and wrapped in two layers of towels in order to avoid skin injuries from the heat. The temperature of the lower back and of each type of pack was recorded at minutes 0 (baseline measurement), 5, 10 and 15 . Temperature was measured by using a digital pyrometer (Etekcity ${ }^{\circledR} \quad$ Lasergrip 774 Non-Contact Infrared Thermometer, Anaheim, CA, USA) at a set distance of $50 \mathrm{~cm}$ and it was held perpendicular to the patient's skin and the pack. The photographic record of the lower back of each subject, before and after each session of superficial thermotherapy, was recorded using a digital camera (Sony ${ }^{\circledR}$ DSC-W610, SONY Corporation, Japan). The camera was placed perpendicular to the lower back, at a distance of $50 \mathrm{~cm}$. The brightness of the photograph was taken into account so as not to affect the analysis of the erythema later. The erythema analysis of the lower back was performed with the freeware Picture Color Analyzer (Shizuoka, Japan; http://www. isao.com). The software measures the red color intensity of each pixel (attributing a value between 1 and 255) within the chosen area. The average red color value obtained in arbitrary units is the result of the following formula: Average red color $=$ total red color value / $(255$ $x$ number of pixels in the area).

\section{Statistical analysis}

The data was analyzed through the statistical program GraphPad Prism ${ }^{\circledR}$ (version 5.01; Inc., El Camino Real, CA USA, 2007). Data is presented as mean \pm standard deviation. The intragroup analysis was performed using the paired t-test. The intergroup comparison was made using one-way analysis of variance (one-way ANOVA) with Tukey's post-hoc test. To evaluate the behavior of packs and the lumbar region temperatures over the time, repeated measures two-way ANOVA with Bonferroni post-hoc test was used. The significance value adopted was $P<0.05$.

\section{RESULTS}

\section{Pack temperature}

The initial temperature of the pack was $56.2 \pm 1.0^{\circ} \mathrm{C}$, $57.8 \pm 3.4^{\circ} \mathrm{C}$ and $49.7 \pm 2.9^{\circ} \mathrm{C}$ for the MHP, SP and GP groups, respectively. The pack that suffered greater reduction in temperature by the end of the session was MHP, with a $14.2{ }^{\circ} \mathrm{C}$ decrease, finishing the process with $42.0 \pm 1.1{ }^{\circ} \mathrm{C}$. The GP presented a decrease of 10.2 ${ }^{\circ} \mathrm{C}$, ending the session at $39.5 \pm 1.0^{\circ} \mathrm{C}$. The $\mathrm{SP}$ group achieved the lowest variation between the start and end of the application, a reduction of $8.2^{\circ} \mathrm{C}$, completing the process of heat transfer at $49.6 \pm 2.7^{\circ} \mathrm{C}$. There were significant differences in pack heat maintenance at $0,5,10$ and 15 minutes (repeated measures two-way ANOVA; $P<0.001$ ) (Figure 2). The MHP and the SP started the protocol with similar temperatures, but the SP sustained a higher temperature during the entire session when compared to MHP (Bonferroni post-hoc test; $P<0.001)$. When compared to the GP group, the SP sustained higher temperatures from the beginning of the protocol until the end of the application (Bonferroni post-hoc test; $P<0.001$ ). Also, GP initial temperature was lower than MHP (Bonferroni posthoc test; $P<0.001)$, remained lower during the $5^{\text {th }}$ and $10^{\text {th }}$ minutes (Bonferroni post-hoc test; $P<0.01$ and $P<0.001$, respectively), but there was no difference at minute 15 .

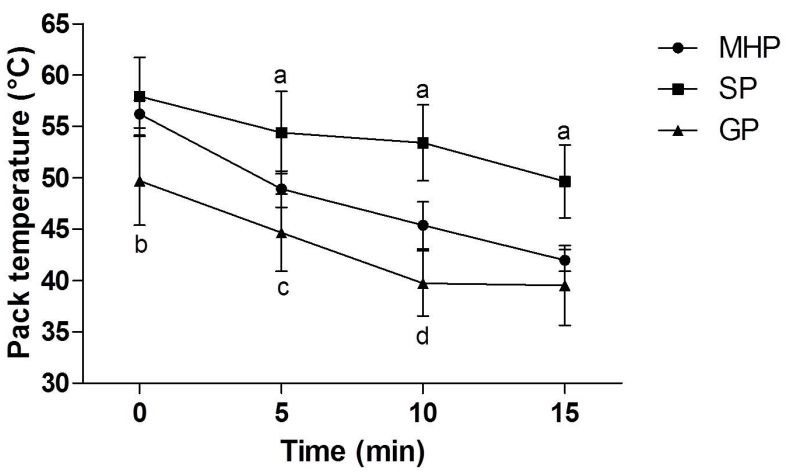

Figure 2. Pack temperature during the 15 minutes treatment session. Data is expressed as mean \pm standard deviation. Statistical test: repeated measures two-way ANOV A, Bonferroni post-hoc test. a: SP vs MHP and SP vs GP, $P<0.001$; $\mathbf{b}$ : MHP vs GP and SP vs GP, $P<0.001$; : MHP vs GP, $P<0.01$; $\mathbf{d}$ : MHP vs GP, $P<0.001$. MHP: moist heat pack, SP: seed pack, GP: gel pack

\section{Lower back temperature}

Along with the pack temperature reduction, there were significant increases in the temperature of the lower back area during the protocol (repeated measures two-way ANOVA; $P<0.001)$. The MHP group initial temperature was $31.2 \pm 0.5^{\circ} \mathrm{C}$ and the final was $38.0 \pm 0.3^{\circ} \mathrm{C}$. The $\mathrm{SP}$ group started the process at a 
temperature of $31.4 \pm 0.8^{\circ} \mathrm{C}$ and ended at $38.3 \pm 0.2^{\circ} \mathrm{C}$. The GP group began the process at a temperature of $31.4 \pm 0.4^{\circ} \mathrm{C}$ and finished at $36.6 \pm 0.8^{\circ} \mathrm{C}$. The GP elicited a lower temperature increase of the lumbar region at 5, 10 and 15 minutes of the sessions when compared to MHP (Bonferroni post-hoc test; $P<0.001, P<0.001$, $P<0.05$, respectively) and SP (Bonferroni post-hoc test; $P<0.001, P<0.001, P<0.01$, respectively) (Figure $3)$. The MHP only promoted a higher increase of the lumbar temperature in the $5^{\text {th }}$ minute of the session in comparison with SP (Bonferroni post-hoc test; $P<0.01$ ). Despite the above, there were no significant differences in the descriptive analysis of the thermal comfort evaluated through the Bedford scale (data not shown).

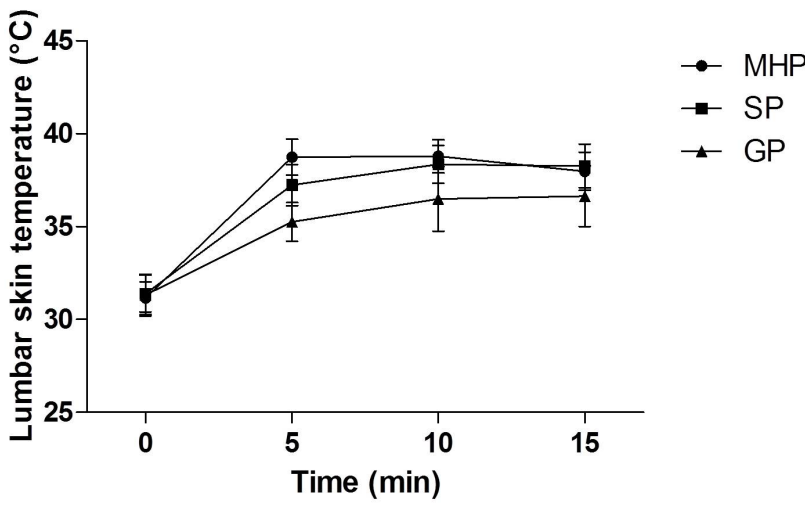

Figure 3. Lumbar region temperature comparison during a 15 minutes thermotherapy session.. Data is expressed as mean \pm standard deviation. Statistical test: repeated measures two-way ANOVA, Bonferroni post-hoc test. a: MHP vs GP and SP vs GP, $\boldsymbol{P}<0.001$; $\boldsymbol{b}$ : MHP vs GP, $\boldsymbol{P}<0.05$; c: SP vs GP, $\boldsymbol{P}<0.01$; $\mathbf{d}$ : MHP vs SP, $\boldsymbol{P}<0.01$. MHP: hot pack, SP: seed pack, GP: gel pack

\section{Erythema occurrence}

The three types of pack elicited significant alterations in occurrence of erythema in the lower back area (oneway ANOVA; $P<0.001$ ) (Figure $4 \mathrm{~A}$ ), as measured by the amount of red color in each pixel of the lumbar region photos. The MHP group presented an initial erythema quantification of $0.69 \pm 0.05$, which was lower than the final quantification of $0.75 \pm 0.04$ (paired t-test; $P<0.001)$. The SP group presented an erythema average of $0.70 \pm 0.03$ that was increased to $0.74 \pm 0.03$ by the end of the procedure (paired t-test; $P<0.001$ ). The GP group presented an average erythema value of $0.69 \pm 0.04$ and in the final evaluation it was increased to $0.71 \pm 0.03$ (paired t-test; $P<0.001)$. The MHP application presented the highest increase of erythema when compared to the SP and GP groups $(0.063 \pm 0.037,0.036 \pm 0.016$, $0.017 \pm 0.007$, respectively; one-way ANOVA; $P<0.05$ ) (Figure 4B).
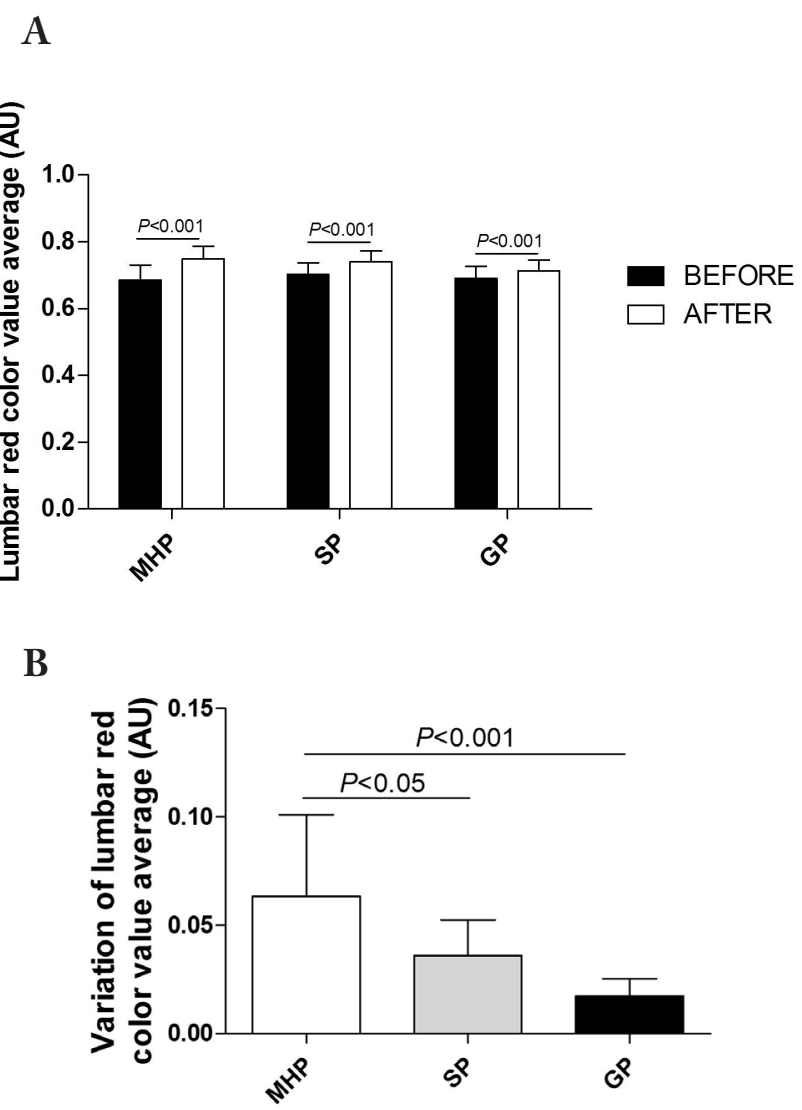

Figure 4. A Erythema evaluation before/after thermotherapy sessions. Data is expressed as meantstandard deviation. Statistical intragroup test: Paired t-test. B Increase of lumbar red color value average at the end of the thermotherapy session. Data are expressed as meanıstandard deviation. Statistical intergroup test: one-way ANOVA, Tukey's post-hoc test. MHP moist heat pack, SP: seed pack, GP: gel pack

\section{Lumbar flexibility}

In the initial evaluation the MHP group presented an average Schober test value of $14.61 \pm 1.42 \mathrm{~cm}$ and in the final evaluation a mean of $15.41 \pm 1.17 \mathrm{~cm}$. The SP group presented an average of $15.12 \pm 1.07 \mathrm{~cm}$ and in the final evaluation a mean of $15.60 \pm 0.96 \mathrm{~cm}$ and the GP group presented an average of $14.60 \pm 0.55 \mathrm{~cm}$ and in the final evaluation a mean of $14.90 \pm 0.74 \mathrm{~cm}$. Significant increases can be observed between the initial and final evaluations when performing an intragroup comparison in all three groups (paired t-test; $P<0.001$ MHP; $P=0.022$ SP; $P=0.001$ GP) (Figure 5A). There was a significant intergroup difference in the variation 
of lumbar flexibility (one-way ANOVA; $P=0.045$ ). The MHP group achieved a change of lower back flexibility of $0.80 \pm 0.67 \mathrm{~cm}$. The SP group had a change of lower back flexibility of $0.48 \pm 0.72 \mathrm{~cm}$ and the GP group showed a lower back flexibility change of $0.21 \pm 0.43 \mathrm{~cm}$. The MHP group was the one that presented a greater increase in the flexibility of the lower back when compared to the GP group (Tukey's post-hoc test; $P<0.05)$ (Figure 5B).

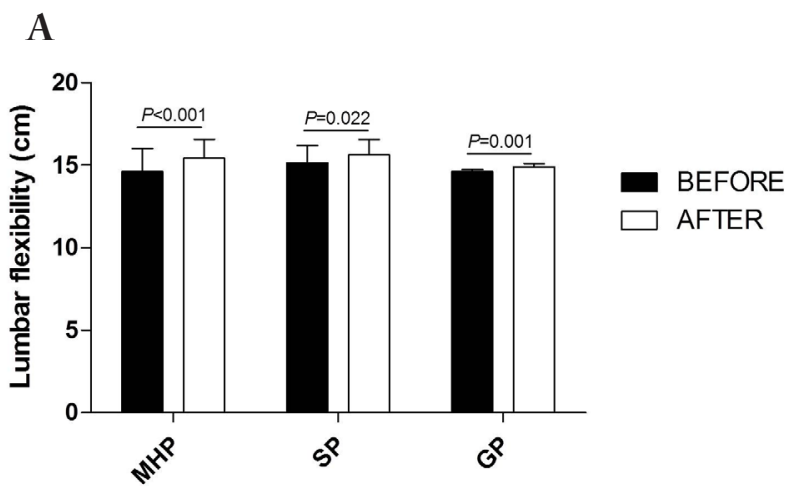

B

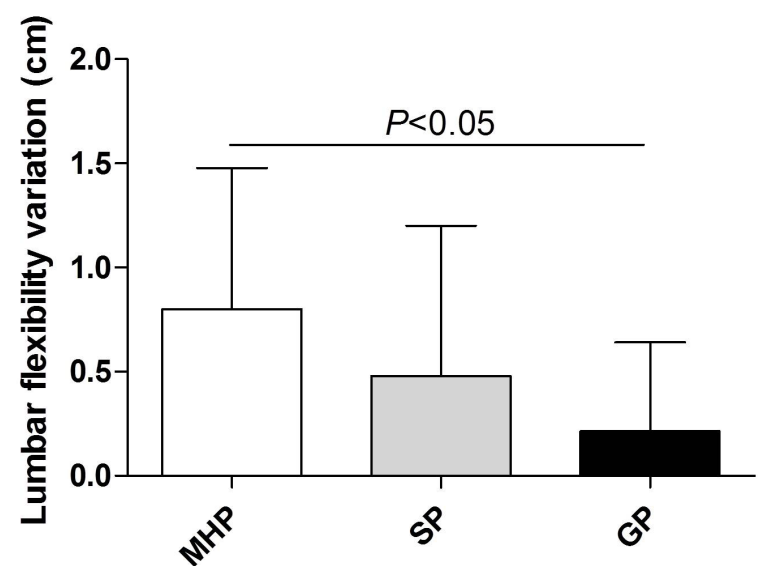

Figure 5. A Schober test comparison before/after thermotherapy sessions. Data are expressed as mean \pm standard deviation. Statistical intragroup test: Paired t-test. B Schober test variation between initial and final test. Data is expressed as mean \pm standard deviation. Statistical intergroup test: one-way ANOVA, Tukey's post-hoc test. MHP: moist heat pack, SP: seed pack, GP: gel pack

\section{DISCUSSION}

It is important to determine the effects of the application of hot packs with different compositions on the flexibility of the lower back in healthy subjects, through the direct use of superficial thermotherapy properties. Many postural and muscular problems in adult lesions are related to the lack of flexibility due to improper alignments of the spine and pelvis, causing problems in the joint's range of motion, muscle pain and injuries and altering posture and motor skills ${ }^{15-17}$.

For proper heat transfer, it is necessary to consider various factors, such as resistance imposed by the skin. The smaller the skinfold, the higher the change of intramuscular temperature ${ }^{18}$. In order to avoid discrepancies in the results associated to this issue, subjects with fat indexes above 14\% (according to Faulkner's formula) and with a body mass index above $25 \mathrm{~kg} / \mathrm{m}^{2}$ were excluded from the study. The application of topical heat at temperatures of around $50^{\circ} \mathrm{C}$ may not be able to significantly increase muscle temperature ${ }^{19}$. However, under these conditions the epidermal-dermal layer can reach temperatures above $40^{\circ} \mathrm{C}^{19}$, similar to those observed in this study, which are capable of increasing blood flow in the hypodermic layer ${ }^{20}$. Nozaki et al. ${ }^{21}$ stated that intramuscular temperature depends on the thickness of the dermal layer, making it necessary to consider the number of layers of insulation between the pack and the skin. Mclean ${ }^{22}$ observed that the magnitude of the temperature transferred from hot packs did not correlate to the expected level of subjectperceived heat or the pack-skin distance, using a depth of 9 layers of towels without specific thickness and without consideration of the impact that the amount of exerted pack-skin compression has in the transmission of heat. This is why two layers of towels were used in this study for the different types of pack to be established, with the same thickness and trying not to generate external pack-skin pressure. It is important to highlight the possible influence of the "compression factor" and its relation to the thermal exchanging area during the application process. The compression can affect the method of heat conduction, because there are irregularities on the surface of the pack that make them not to fit perfectly. It causes a series of spaces occupied by air that produce greater resistance, since air is a poor heat conductor, unlike the high conductivity which occurs during direct pack-skin contact ${ }^{23}$.

From the 3 types of hot pack used, the group that reached the highest pack temperature was the SP group, showing significant differences when compared with the MHP and GP groups during the whole evaluation. The average initial temperature of the lower back recorded in this study do not have 
significant differences among the three groups, however, differences were found within the 5 minutes after heat exposure. The lower back temperatures of the MHP and SP groups were significantly greater when compared to the GP group, and the MHP group was better for transmitting heat when compared to the SP group. The pack that presented the highest heat transfer after 5 minutes of the procedure was the MHP group, despite the fact that the SP was the one that achieved the highest pack temperature. It is opposed to the assumption of Myrer et al. (1997) ${ }^{18}$, in which the higher the temperature gradient between the pack and the body, the higher the heat transferred. This discrepancy could be explained by the type of heat generated by the MHP, its moisture condition and the specific heat property of the hot pack material. Moist heat can penetrate more quickly than dry heat because water molecules conduct heat better than air molecules, so the moist heat can be used at lower temperatures and with shorter exposure periods than dry heat ${ }^{24}$.

When comparing the difference between initial and final pack temperatures, the MHP group was the one that achieved the greatest heat loss, obtaining significant differences from the SP and GP groups, indicating that it was the group that had the greatest ability to transfer heat. The second highest temperature reduction was observed in the GP group, but it does not perform an optimal heat transfer to the skin, which can be explained by the loss of the gel thermoreversible capacity that is altered by changing its freezing and boiling point according to the gel manufacturing catalog (Colony Processing Inc.). The pack that managed to maintain its temperature, showing significant differences throughout the evaluation when compared with the MHP and GP groups was the SP group, while this may be attributed to its physical properties. However, other studies, from which to make a comparison, were not found.

The theoretical temperatures mentioned for the MHP and GP groups were not achieved by the protocol established for clinical use, on which hot packs reach an initial temperature of $71-79^{\circ} \mathrm{C}^{7}$. None of the packs used reached that temperature, indicating that these types of pack, despite being kept in a pack device at a constant temperature $80^{\circ} \mathrm{C}^{21}$, fail to accomplish a complete transfer of heat. Gel packs reached a maximum theoretical temperature of $52^{\circ} \mathrm{C}^{25}$ and the time suggested to heat these packs is 55 seconds (Orthomed
Instrument Catalog, inc.), which was insufficient to reach this temperature.

The erythema analysis was carried out through the comparison of the lower back, red pixel count before and after the heat procedure. It showed significant increases for the three groups, even though the GP group showed less variation in temperature in the lower back. Due to the above, it is necessary to protect and verify the condition of the skin every 5 minutes when this type of therapy is applied ${ }^{7}$.

Most studies investigated some kind of thermotherapy application in conjunction with stretching protocols ${ }^{9,26-28}$; so the heat effects are mostly indirectly evaluated ${ }^{29}$. It is therefore necessary to more objectively determine the amount of heat that each type of pack transfers to the corporal zone and how that affects flexibility. Maintaining flexibility preserved during life is an essential aspect of clinical practices, due to its functional consequences that entail limiting the patient's ability to perform household activities, professional activities or sporting tasks, affecting their quality of life ${ }^{30}$.

It is expected that a healthy person gets a variation of $5 \mathrm{~cm}$ in the Schober test ${ }^{31}$. When completing the process of applying superficial thermotherapy through different types of pack, the final Schober test evaluation confirmed that there was a change in the lengthening capacity of soft tissues, resulting in a clinically significant increase of lumbar spine flexibility.

The intragroup analysis showed significant improvement in the flexibility of the three groups after the application of heat through superficial thermotherapy. It may be due to the therapeutic effects of the heat in the tissues, including alterations of viscoelastic properties, increased muscle flexibility ${ }^{2,3,5}$ and decreased articularstiffness ${ }^{6-8}$. These benefits can alter the properties of the soft tissue of the lower back, increasing tissue elongation (creep), which implies a further relaxation at the muscular leve1 $1^{10,32}$.

The three hot packs tested presented different physical properties, but the intergroup analysis showed significant differences in the lumbar flexibility variation between the MHP and GP groups. The MHP provided a more pronounced increase in the lengthening of lower back tissues. This study reveals the importance of choosing an appropriate pack for clinical use to achieve the best desired therapeutic effects. Further research should be developed in this area. 


\section{Limitations}

The study was conducted on healthy, young subjects, without any follow up evaluation after the last thermotherapy session.

\section{CONCLUSION}

The pack that achieved the best heat transfer to the lower back area was the MHP and the one that preserved its temperature for the longest period of time was the SP. All three packs caused occurrences of lower back erythema, which was more pronounced in the MHP group. The three types of pack used in this study achieved the therapeutic goal of increasing flexibility in the lower back after superficial heat transfer. The greatest increase in lumbar flexibility was produced by MHP.

\section{ACKNOWLEDGMENTS}

The authors would like to thank Mauricio Garrido for his contribution in writing the manuscript and Prof. Ximena Jara and Prof. Hugo Tapia for their scientific advice.

\section{REFERENCES}

1. Tagawa T, Imaizumi T, Endo T, Shiramoto M, Harasawa $Y$, Takeshita A. Role of nitric oxide in reactive hyperemia in human forearm vessels. J Am Heart Assoc. 1994;90(5):2285-90

2. Jerrold S, Petrofsky S, Lohman E, Jin H, García J, Anders A, et al. Determination of the conductive heat exchange of the skin in relation to environmental temperature. J Appl Res Clin Exp Ther. 2006;6(2):157-69.

3. Funk D, Swank A, Adams K, Treolo D. Efficacy of moist heat pack application over static stretching on hamstring flexibility. J. Strength Cond Res. 2001;15(1):123-6.

4. Matsumoto S, Kawahira K, Etoh S, Ikeda S, Tanaka N. Shortterm effects of thermotherapy for spasticity on tibial nerve F-waves in post-stroke patients. Int J Biometeorol. 2006;50(4):243-50.

5. Leung $M$, Cheing $G$. Effects of deep and superficial heating in the management of frozen shoulder. J Rehabil Med. 2008;40(2):145-50.

6. Sreniawski S, Cordova M, Ingeroll C. A comparison of hot packs and light or moderate exercise on rectus femoris temperature. J Athl Train. (Suppl.). 2002;37(2S):S-104.
7. Pavez F. Superficial physical agents and pain: analysis of its effectiveness in the light of scientific evidence. Rev Soc Esp Dolor. 2009;16(3):182-9.

8. Silva S, Oliveira D, Jaques M, Araújo R. Effects of cryotherapy and thermotherapy associated with static stretching on the flexibility of hamstring muscles. Motricidade. 2010;6(4):55-6.

9. Lin Y. Effects of thermal therapy in improving the passive range of knee motion: comparison of cold and superficial heat applications. Clin Rehabi. 2003;17(6):618-23.

10. Bleakley CM, Costello AJ. Do thermal agents affect range of movement and mechanical properties in soft tissues? A systematic review. Arch Phys Med Rehabil. 2013;94:149-63.

11. Cameron MH. Thermal agents: cold and heat. In: Cameron $\mathrm{MH}$. Physical agents in rehabilitation. 3rd ed. St. Louis: Elsevier Saunders; 2009. p. 124-8.

12. GraphPad Software [homepage on the internet][cited 2012 Jun 4]. Disponível em: http://www.graphpad.com/ quickcalcs/index.cfm

13. Miot HA. Tamanho da amostra em estudos clínicos e experimentais. J Vasc Bras. 2011;10(4):275-8.

14. Knight CA, Rutledge CR, Cox ME, Acosta M, Hall SJ. Effect of superficial heat, deep heat, and active exercise warm-up on the extensibility of the plantar flexors. Phys Ther. 2001;81:1206-14.

15. French S, Cameron M, Walker B, Reggars J, Esterman A. A Cochrane review of superficial heat or cold for low back pain. Spine. 2006;20(31):998-1006.

16. Middelkoop M, Rubinstein S, Kuijpers T, Verhagen A, Ostelo $\mathrm{R}$, Koes B, et al. Review on the effectiveness of physical and rehabilitation interventions for chronic non-specific low back pain. Eur Spine J. 2011;20(1):19-39.

17. Hoeger W, Hoeger S. Muscular Flexibily. In: Hoeger W, Hoeger S. Lifetime physical fitness and wellness: a personalized program. 10. ed. Belmont: Wadsworth; 2011. p. 255-75.

18. Myrer J, Measom G, Durrant E, Fellingham G. Cold- and hotpack contrast therapy: subcutaneous and intramuscular temperature. J Athl Train. 1997;32(3):238-41.

19. Davis P, Gaborski T, Pardo J, Patcha P, Whitman K. The effects of topical heating for therapeutic uses.eCommons@ Cornell. [homepage on the Internet]. Cornell University, 2004. [updated 2004 Nov 12; cited 2012 Dic 4]. Available from: http://ecommons.cornell.edu/handle/1813/210.

20. Okada K, Yamaguchi T, Minowa K, Inoue N. The influence of hot pack therapy on the blood flow in masseter muscles. J Oral Rehabil. 2005;32(7):480-6.

21. Nozaki S, Kawai M, Shimoyama R, Futamura N, Matsumura $\mathrm{T}$, Adachi K, et al. Range of motion exercise of temporomandibular joint with hot pack increases occlusal force in patients with Duchenne muscular dystrophy. Acta Myol. 2010;29(3):392-7.

22. McLean D. The use of cold and superficial heat in the treatment of soft tissue injuries. $\mathrm{Br} \mathrm{J}$ Sports Med. 1989;23(1):53-4.

23. Ramesh G, Prabhu NK. Review of thermo-physical properties, wetting and heat transfer characteristics of nanofluids and their applicability in industrial quench heat treatment. Nanoscale Res Lett. 2011;6(1):1-15. 
24. Kim J, Lee L, Lee W, Lee J, Kim M, Kim B, et al. Temporal changes in skin temperature caused by wet and dry heat in healthy volunteers. J Phys Ther Sci. 2012;24(12):1209-13.

25. Strax T, Gonzalez P, Cuccurullo, S. Chapter 8. Physical Modalities, Therapeutic Exercise, Extended Bedrest, and Aging Effects. In: Cuccurullo, S, editor. Physical Medicine and Rehabilitation Board Review. 2. ed. New York: Editorial Demos Medical; 2004. p. 553-84.

26. Lee $\mathrm{G}, \mathrm{Ng} \mathrm{G}$. Effects of stretching and heat treatment on hamstring extensibility in children with severe mental retardation and hypertonia. Clin Rehabil. 2008;22(9):771-9.

27. Wiwatkul W, Tasana-anunchai S, Phanich-attra W. A comparison of hot pack with stretching exercise and Thai massage to myofascial pain syndrome in neck and upper back pain. J Prapokklao Hosp Clin Med Educ Centr. 2012;25(2):114-23.

28. Patel H, Desai D, Soni H, Soni K, Shah C. A comparative study of effectiveness between superficial heat and deep heat along with static stretching to improve the plantar flexors flexibility in females wearing high heel foot wears. Indian J Physiother Occup Ther. 2013;7(1):58-64.

29. Robertson J, Ward R, Jung P. The effect of heat on tissue extensibility: a comparison of deep and superficial heating. Arch Phys Med Rehabil. 2005;86(4):819-25.

30. Mayer J, Ralph L, Look M, Erasala G, Verna J, Matheson L, et al. Treating acute low back pain with continuous low-level heat wrap therapy and/or exercise: a randomized controlled trial. Spine J. 2005;5(4):395-403

31. Fernández C, Blanco C, del Amo A, Miangolarra J. Relationship among mobility, functionality and quality of life in subjects presenting with ankylosing spondylitis. Fisioterapia. 2006;28(3):143-5.

32. Guede D, González P, Caeiro J. Biomechanics and bone (I): Basic concepts and classical mechanical tests. Miner Metab Rev Osteoporos. 2013;5(1):43-50. 